\title{
Combining ability of twelve maize populations ${ }^{(1)}$
}

\author{
Elton Vacaro(2), José Fernandes Barbosa Neto ${ }^{(3)}$, Diego Girardi Pegoraro(4), \\ Claudio Natalino Nuss ${ }^{(2)}$ and Leo Duc Haa Conceição( ${ }^{(5)}$
}

\begin{abstract}
Genetic progress depends on germplasm quality and breeding methods. Twelve maize populations and their crosses were evaluated to estimate combining ability and potential to be included as source populations in breeding programs. Plant height, point of insertion of the first ear, number of ears per plant, number of grains per ear, root and stalk lodging and grain yield were studied in two locations in Brazil, during the 1997/98 season. Genotype sum of squares was divided into general (GCA) and specific (SCA) combining ability. Results indicated the existence of genetic divergence for all traits analyzed, where additive effects were predominant. The high heterosis levels observed, mainly in Xanxerê, suggested the environmental influence on the manifestation of this genetic phenomenon. Populations revealed potential to be used in breeding programs; however, those more intensively submitted to selection could provide larger genetic progress, showing the importance of population improvement for the increment of the heterosis in maize.
\end{abstract}

Index terms: Zea mays, germplasm, heterosis, genetic variation.

Capacidade combinatória de doze populações de milho

\begin{abstract}
Resumo - O progresso genético depende da qualidade do germoplasma e dos métodos de melhoramento empregados. Neste trabalho foram avaliadas doze populações de milho e seus cruzamentos para avaliar suas capacidades combinatórias e seu potencial de inclusão em programas de melhoramento de milho no sul do Brasil. A estatura de planta, ponto de inserção da primeira espiga, número de espigas por planta, número de grãos por espiga, acamamento, quebramento e rendimento de grãos foram avaliados em dois locais, em 1997/98. A soma de quadrados de genótipos foi dividida em capacidade geral (CGC) e específica (CEC) de combinação. Os resultados indicaram a existência de variabilidade genética em todas as características analisadas, em que os efeitos aditivos foram predominantes. Os altos níveis de heterose observados, principalmente em Xanxerê, sugerem forte influência ambiental na manifestação deste fenômeno genético. As populações revelaram potencial para serem utilizadas em programas de melhoramento; entretanto, aquelas que sofreram seleção prévia mais intensa poderiam proporcionar progresso genético maior, demonstrando, assim, a importância do melhoramento de populações para o incremento da heterose em milho.
\end{abstract}

Termos para indexação: Zea mays, germoplasma, heterose, variação genética.

(1) Accepted for publication on February 8, 2001.

(2) Agroeste Sementes Ltda., Rua Antônio Vacaro, 130, CEP 89820-000 Xanxerê, SC. E-mail: evacaro@yahoo.com

(3)Universidade Federal do Rio Grande do Sul (UFRGS), Fac. de Agronomia, Dep. de Plantas de Lavoura, Caixa Postal 776, CEP 91501-970 Porto Alegre, RS. CNPq Scholar. E-mail: jfbn@vortex.ufrgs.br

(4) Fundação Pró-Sementes de Apoio à Pesquisa, Rua Diogo de Oliveira, 640, CEP 99025-130 Passo Fundo, RS. E-mail: dgpegoraro@hotmail.com

${ }^{(5)}$ UFRGS, Fac. de Agronomia, Dep. de Plantas de Lavoura. PIBIC/CNPq Scholar.

\section{Introduction}

Maize (Zea mays L.) productivity has grown in Brazil in the last years due to improved crop management and release of new varieties. Plant breeding has been responsible for the development of these new varieties with better plant architecture, high disease and insect resitance, better root system, and superior grain yield. Exploitation of heterosis is one of the main reasons for the success of maize seed companies (Stuber, 1994). Heterosis has been considered as superior to the hybrid compared to 
the parents, and is dependent on heterozygosity and dominance (Hallauer \& Miranda Filho, 1988).

However, for the efficient use of heterosis the development of populations with high combining ability is fundamental (Griffing, 1956; Vasal et al., 1992a). The value of any population depends on its potential per se and its combining ability in crosses. As a consequence, germplasm evaluation is a decisive aspect in maize breeding programs (Stuber, 1994). The evaluation of populations can support hybrid programs and supply good open pollinated varieties, since populations with high frequency of favorable alleles are important sources for plant selection (Miranda Filho \& Viégas, 1987). In addition, this evaluation will allow breeders to concentrate efforts in those populations with higher potential of producing superior progenies.

Several researchers have been using diallel analysis to determine combining ability (Brenner et al., 1991; Pixley \& Bjarnason, 1993; Ferreira et al., 1995; Pérez-Velásquez et al., 1995). The diallel cross has been defined as the group of all possible crosses among several genotypes. The diallel is simple to manipulate in maize and supplies important information about the studied populations, as general and specific combining ability, genetic variances, heritability and maternal effects, among others. This analysis also permits an evaluation of the populations per se.

The objective of this work was to study twelve maize populations, determining their combining ability and potential use as source populations in breeding programs for the South of Brazil.

\section{Material and Methods}

The populations used in this study presented diversified origin and they were submitted to different selection pressures. The populations were: Cone Sur (Csur - flint, yellow), Caribe-Mexico (Cmex - semident, red), Sintético 34 (St34 - flint, yellow), Composto Amarelo Dentado (Cad - dent, yellow), Población 26 (Pb26 - semiflint, orange), Población 62 (Pb62 - dent, yellow), Pool 25 (P125 semiflint, orange), Pool 26 (P126 - dent, yellow), Amarillo del Bajio (AdB - dent, yellow), Tuxpeño Amarelo (TuxA - dent, yellow), Nitroflint (Nit - flint, orange), and Sintético Elite (StEl - semident, orange). Their potential to contribution in breeding programs was evaluated through a diallel cross. Crosses, including reciprocals, were performed in the winter of 1997 in the central Brazil. Pollen was collected from 30 plants and used to pollinate ten plants from the other population. Each entry was composed by the cross and its reciprocal, allowing better sampling of the hybrid. Experiments were planted in a random block design with three replications in 1997/98 at Estação Experimental Agronômica of the Universidade Federal do Rio Grande do Sul in Eldorado do Sul, RS (latitude: $30.1^{\circ} \mathrm{S}$, longitude: $51.6^{\circ} \mathrm{W}$, altitude: $19 \mathrm{~m}$ ) and at Estação Experimental of Agroeste Sementes, in Xanxerê, SC (latitude: $26.9^{\circ} \mathrm{S}$, longitude: $52.4^{\circ} \mathrm{W}$, altitude: $800 \mathrm{~m}$ ). Each plot was comprised of two $5 \mathrm{~m}$ long rows and spaced $0.80 \mathrm{~m}$ apart, resulting in an area of $8 \mathrm{~m}^{2}$.

Sowing was accomplished on October 18, 1997 in Xanxerê with a density of 50,000 plants/ha. Fertilization was $20 \mathrm{~kg} / \mathrm{ha}$ of N, $80 \mathrm{~kg} / \mathrm{ha}$ of $\mathrm{P}_{2} \mathrm{O}_{5}$, and $80 \mathrm{~kg} / \mathrm{ha}$ of $\mathrm{K}_{2} \mathrm{O}$. At V6 (Ritchie et al., 1998), a dose of $70 \mathrm{~kg} / \mathrm{ha}$ of $\mathrm{N}$ was supplied. In Eldorado do Sul, sowing was on October 30, 1997 with a density of 60,000 plants/ha. Base fertilization corresponded to $12.5 \mathrm{~kg} / \mathrm{ha}$ of $\mathrm{N}, 50 \mathrm{~kg} / \mathrm{ha}$ of $\mathrm{P}_{2} \mathrm{O}_{5}$, and $50 \mathrm{~kg} / \mathrm{ha} \mathrm{K}_{2} \mathrm{O}$. Nitrogen was also applied at V6 in a dose of $50 \mathrm{~kg} / \mathrm{ha}$. The crop was harvested manually. The evaluated traits were: plant height $(\mathrm{cm})$, first ear insertion $(\mathrm{cm})$, number of ears per plant, number of grains per ear, root and stalk lodging (\%), and grain yield ( $\mathrm{kg} / \mathrm{ha})$.

Data were initially submitted to analysis of variance. The genotypic effects that were statistically significant were further divided according to diallel analysis method two, model I, from Griffing (1956). This method is appropriate for fixed effects for genotypes and allows estimation of general and specific combining ability effects. Percent root and stalk lodging were submitted to the arcsine of the square root transformation.

\section{Results and Discussion}

Experimental results allowed to identify the genetic variability among the 12 maize populations for all traits. In Eldorado do Sul, the F test did not reveal significant differences among populations for any trait. Average values showed low grain yield $(2,391 \mathrm{~kg} / \mathrm{ha})$, reduced number of ears per plant $(0.68)$, low plant height $(199 \mathrm{~cm})$ and first ear insertion $(106 \mathrm{~cm})$, and reduced root $(3.8 \%)$ and stalk $(2.3 \%)$ lodging. This poor performance observed at Eldorado do Sul can be attributed to dry weather conditions during the season and to competition with weeds. On the other hand, in Xanxerê the analysis of vari- 
ance revealed significant differences at 5\% level of probability for grain yield, plant height, first ear insertion, and percent of root lodging (Table 1). In this location, the averages for the different traits were numerically superior when compared to those of Eldorado do Sul, especially for grain yield, plant height, first ear insertion, and root and stalk lodging percentage. The group formed by populations AdB, $\mathrm{Pb} 26$, and $\mathrm{P} 125$ had the largest grain yield. On the other hand, populations $\mathrm{St} 34$ and $\mathrm{Pb} 62$ presented reduced plant height and first ear insertion. Populations CSur, St34, Pb26, Pb62, Pl26, and TuxA showed the lowest root lodging.

Parent populations were divided in dent (CaribeMexico, Composto Amarelo Dentado, Población 62, Pool 26, Amarillo del Bajio, Tuxpeño Amarelo e Sintético Elite) and flint types (Cone Sur, Sintético 34, Población 26, Pool 25 e Nitroflint). All of them have been under selection in breeding programs. Composto Amarelo Dentado is related to Pool 26, composed by Eto, Tuxpeño, and other tropical germplasm, and had five cycles of selection. Población 62 is a QPM (Quality Protein Maize) and wide base population from Cimmyt. Pool 26, Pool 25 and Sintético Elite were formed by a wide range of tropical and semi-tropical germplasm and they were under selection for several cycles in the central Brazil. Amarillo del Bajio was introduced from Cimmyt in the 70's and it is well adapted to Brazilian conditions. It presents high genetic variability for $\mathrm{N}$ uptake efficiency. Tuxpeño Amarelo was originated from a mutation of Tuxpeño and came from Cimmyt. It was under selection pressure for several cycles for adaptation and ear covering. Population Cone Sur was formed by the combination of two elite germplasm followed by two cycles of mass selection. Sintético 34 is composed by several elite inbreds from Brazil and Argentina. Población 26 is Mescla Amarilla and had five cycles of selection in Brazil. Nitroflint is composed of Cateto, Eto, and Caribe germplasm. This population was selected for several cycles aiming $\mathrm{N}$ use efficiency.

Hybrid superiority has been widely recognized; however, not any combination is able to determine hybrid advantage. It is necessary to evaluate parents in order to maximize heterotic response. Analysis of combining ability allows the choice of parental populations, and is an important aspect to be considered in breeding programs. The use of genotypes with high combining ability will give superior

Table 1. Averages of grain yield (kg/ha) (GY), number of years per plant (NEP), number of grains per ear (NGE), plant height $(\mathrm{cm})(\mathrm{PH})$, first ear insertion $(\mathrm{cm})(\mathrm{FEI})$, root lodging $(\%)(\mathrm{RL})$, and stalk lodging (\%) (SL) for 12 maize populations (Xanxerê, SC, 1997/98) (1). $^{(1)}$

\begin{tabular}{llllllcr}
\hline Population & GY & NEP & NGE & PH & FEI & RL & SL \\
\hline CSur & $5,076 \mathrm{bcde}$ & 1.0 & 434 & $195 \mathrm{cde}$ & $107 \mathrm{bcde}$ & $1.7 \mathrm{c}$ & 11.7 \\
CMex & $3,892 \mathrm{ef}$ & 0.9 & 582 & $244 \mathrm{a}$ & $145 \mathrm{a}$ & $15.1 \mathrm{ab}$ & 22.1 \\
St34 & $4,288 \mathrm{def}$ & 1.0 & 499 & $177 \mathrm{e}$ & $88 \mathrm{e}$ & $11.3 \mathrm{c}$ & 6.0 \\
CAd & $5,673 \mathrm{abcd}$ & 1.0 & 717 & $236 \mathrm{ab}$ & $137 \mathrm{ab}$ & $5.1 \mathrm{a}$ & 22.4 \\
Pb26 & $6,179 \mathrm{ab}$ & 0.9 & 547 & $205 \mathrm{bcde}$ & $105 \mathrm{cde}$ & $13.0 \mathrm{c}$ & 12.6 \\
Pb62 & $5,066 \mathrm{bcde}$ & 1.1 & 617 & $190 \mathrm{de}$ & $101 \mathrm{de}$ & $4.2 \mathrm{c}$ & 20.3 \\
P125 & $6,038 \mathrm{ab}$ & 0.9 & 680 & $229 \mathrm{abc}$ & $132 \mathrm{abc}$ & $19.6 \mathrm{bc}$ & 28.2 \\
Pl26 & $5,935 \mathrm{abc}$ & 1.0 & 641 & $215 \mathrm{abcd}$ & $116 \mathrm{abcde}$ & $1.6 \mathrm{c}$ & 20.0 \\
AdB & $6,694 \mathrm{a}$ & 1.1 & 563 & $210 \mathrm{abcde}$ & $121 \mathrm{abcd}$ & $3.1 \mathrm{abc}$ & 32.1 \\
TuxA & $5,717 \mathrm{abcd}$ & 1.0 & 583 & $202 \mathrm{bcde}$ & $109 \mathrm{bcde}$ & $5.8 \mathrm{c}$ & 14.3 \\
Nit & $3,445 \mathrm{f}$ & 1.1 & 563 & $206 \mathrm{abcde}$ & $111 \mathrm{bcde}$ & $2.5 \mathrm{abc}$ & 7.6 \\
StEl & $4,543 \mathrm{cdef}$ & 1.0 & 580 & $230 \mathrm{abc}$ & $131 \mathrm{abc}$ & $5.9 \mathrm{abc}$ & 6.3 \\
\hline Mean & 5,212 & 1.0 & 584 & 212 & 117 & 7.4 & 17.0 \\
C V (\%) & 9.3 & 11.1 & 19.2 & 6.0 & 8.7 & 34.9 & 36.2 \\
\hline
\end{tabular}

${ }^{(1)}$ Means followed by the same letter do not differ significantly by Tukey test at $5 \%$ of probability. 
hybrids and segregant populations with large genetic variability.

Significant genotype mean square was divided into GCA and SCA. In Eldorado do Sul, F test detected significant differences $(\alpha=0.01)$ for grain yield, number of ears per plant, plant height, and first ear insertion. Root lodging was significant at the level of $5 \%$. GCA mean square was significant at the level of $1 \%$ of probability for all traits (Table 2). On the other

Table 2. General combining ability effects for grain yield (GY), number of ears per plant (NEP), plant height (PH), first ear insertion (FEI), and percentage of root lodging (RL) in 12 maize populations (Eldorado do Sul, RS, 1997/98).

\begin{tabular}{lrrrrc}
\hline Population & GY & NEP & PH & FEI & RL \\
\hline Csur & 130 & 0.04 & 0.2 & -0.9 & 0.00 \\
Cmex & 208 & 0.05 & 12.8 & 10.1 & 0.03 \\
St34 & 277 & 0.05 & -10.9 & -6.5 & -0.01 \\
Cad & 65 & 0.02 & 1.2 & 0.7 & 0.08 \\
Pb26 & -466 & -0.07 & -6.8 & -7.7 & -0.03 \\
Pb62 & 72 & 0.03 & -5.9 & -7.0 & -0.04 \\
P125 & -196 & -0.04 & 7.5 & 5.9 & 0.00 \\
Pl26 & -210 & -0.01 & 0.2 & 0.2 & 0.00 \\
AdB & 420 & 0.00 & -4.9 & 0.1 & 0.00 \\
TuxA & 218 & -0.02 & -1.8 & -2.7 & -0.02 \\
Nit & -291 & -0.03 & 6.7 & 5.5 & -0.01 \\
StE1 & -227 & -0.03 & 1.7 & 2.3 & 0.00 \\
\hline
\end{tabular}

hand, in Xanxerê, $\mathrm{F}$ test for genotypic effects revealed significant differences at the level of $1 \%$ of probability in all traits. The same was obtained for GCA effects (Table 3 ). The highly significant mean squares for GCA observed for all traits, except percent of stalk lodging in Eldorado do Sul, indicated that some populations presented superior behavior in their crosses when compared with others included in the diallel. In general, populations with large GCA exhibited potential as parents of hybrid varieties, as well as for inclusion in breeding programs, since they may contribute with superior alleles in new populations.

Several crosses demonstrated high SCA for grain yield, percent of root and stalk lodging, and plant height (Figure 1). Populations with high GCA also revealed hybrids with high SCA; however, population StEl (average GCA) presented high frequency of crosses with significant SCA, suggesting that this germplasm presents alleles with non addictive effects. Populations with high SCA, as StEl, may have sufficient power for hybrid formation, since their lines will give combinations of excellent agronomic value. In this study, the GCA mean square was greater than SCA mean square for all evaluated traits, indicating a predominance of addictive effects. Several researchers also have indicated additive effects in the inher-

Table 3. General combining ability effects for grain yield (GY), number of ears per plant (NEP), number of grains per ear (NGE), plant height (PH), first ear insertion (FEI), percentage of root lodging (RL), and percentage of stalk lodging (SL) in 12 maize populations (Xanxerê, SC, 1997/98).

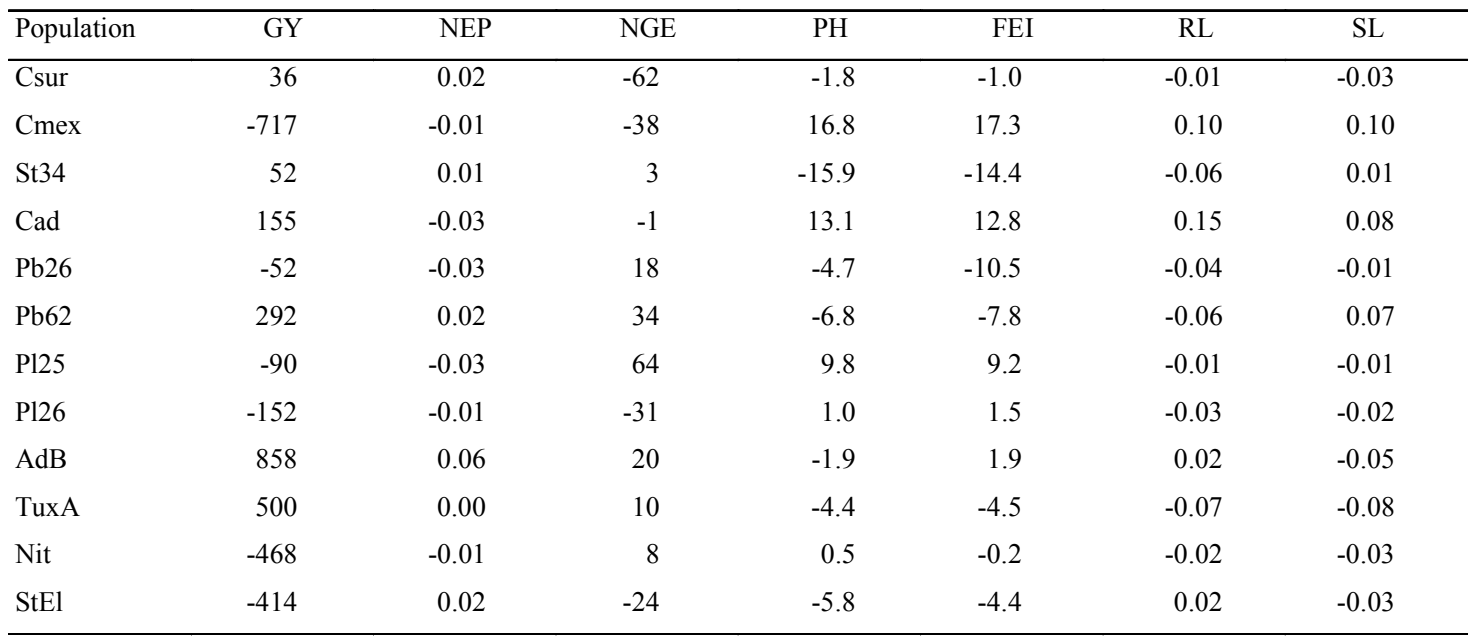


itance of different agronomic traits in maize (Mungoma \& Pollak, 1988; Vasal et al., 1992b). In relation to grain yield, StEl was the parent with more combinations showing high SCA effects in Eldorado do Sul and Xanxerê (Table 4). Cone Sur also demonstrated combinations with high SCA, mainly in Eldorado do Sul.

The most promising populations for breeding programs presented high GCA effects, reflecting the importance of additivity in the control of agronomic traits, including grain yield. Superior populations in this study were AdB, Pb62 and TuxA (Mexico), St34 (Argentine), and StEl (Brazil). These populations provided crosses with large grain yield (especially AdB and TuxA), large number of ear per plant, low root lodging (except AdB), low stalk lodging (except $\mathrm{Pb} 62$ and St34), short plants, and low first ear insertion (except AdB). As a consequence, these populations should be considered as priority for inclusion in breeding programs. Brenner et al. (1991), working with a similar group of populations, also highlighted population $\mathrm{AdB}$ as superior. On the other hand, some populations that did not present high combining ability, demonstrated potential to contribute with specific traits. For example, population $\mathrm{Pb} 26$ contributed to plant height reduction and low first ear insertion point, decreasing root and stalk lodging. Also population P125 may contribute to increase the number of grains per ear in maize breeding programs.

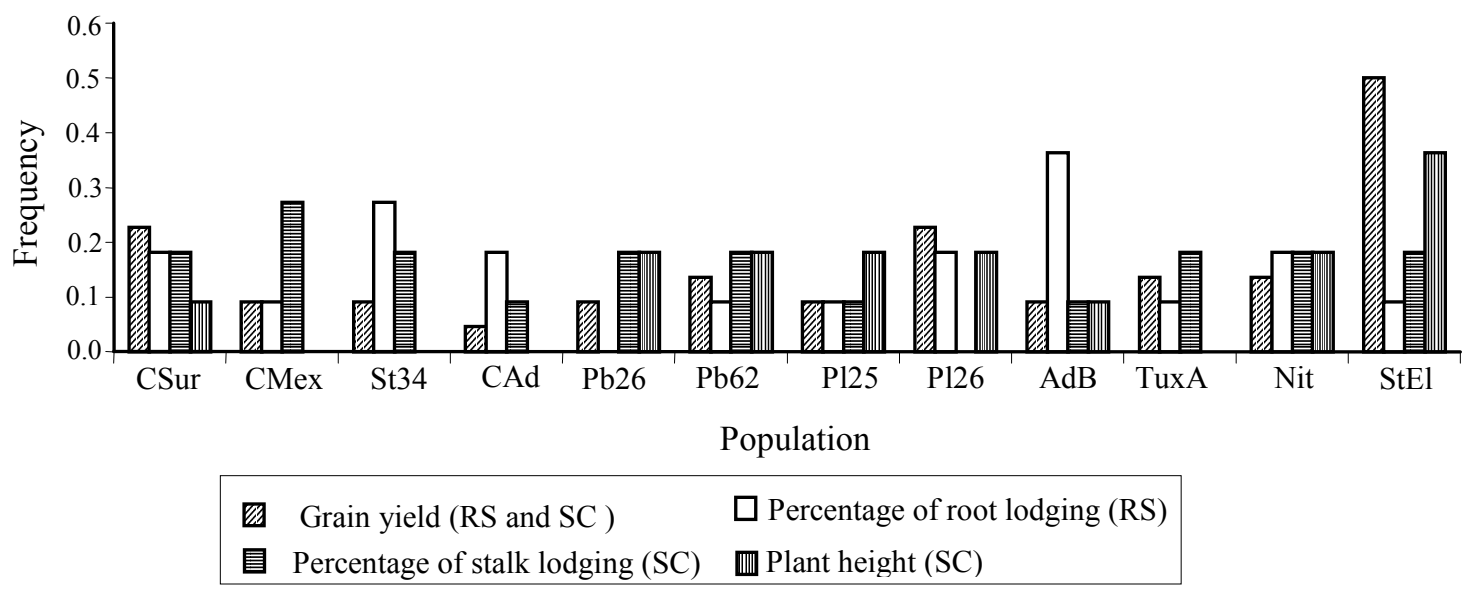

Figure 1. Frequency of crosses with larger specific combining ability values for different traits evaluated in Eldorado do Sul, RS and Xanxerê, SC. 1997/98.

Table 4. Specific combining ability effects $\left(\mathrm{s}_{\mathrm{ij}}\right)$ for grain yield $(\mathrm{kg} / \mathrm{ha})$ in 66 maize evaluated in Eldorado do Sul, RS (above diagonal) and Xanxerê, SC (below diagonal) (Xanxerê, SC, 1997/98).

\begin{tabular}{|c|c|c|c|c|c|c|c|c|c|c|c|c|}
\hline Population & CSur & CMex & St34 & CAd & $\mathrm{Pb} 26$ & $\mathrm{~Pb} 62$ & $\mathrm{P} 125$ & $\mathrm{P} 126$ & $\mathrm{AdB}$ & TuxA & Nit & StEl \\
\hline Csur & & $-1,114$ & -83 & -334 & -269 & -918 & 186 & 1,388 & 340 & 1,107 & -340 & 1,146 \\
\hline CMéx & 293 & & -219 & -229 & 113 & 292 & 50 & 721 & 344 & -89 & -41 & 375 \\
\hline St34 & -481 & -14 & & 287 & 250 & -429 & 720 & 239 & 325 & -877 & 178 & 252 \\
\hline $\mathrm{Pb} 26$ & -85 & -162 & 17 & -81 & & 45 & -177 & 257 & -831 & 377 & 318 & 790 \\
\hline $\mathrm{Pb} 62$ & 154 & -283 & 38 & 370 & -664 & & -211 & 672 & -609 & -208 & 597 & 1,550 \\
\hline $\mathrm{P} 125$ & 67 & 238 & 349 & 54 & 159 & -141 & & 20 & 304 & 85 & -697 & -56 \\
\hline $\mathrm{AdB}$ & -470 & 441 & 96 & -296 & 187 & 329 & -293 & -380 & & 581 & 732 & 632 \\
\hline TuxA & -238 & -737 & 494 & -477 & 16 & 574 & 173 & -408 & 382 & & 128 & 628 \\
\hline Nit & 719 & 1,191 & -135 & -470 & 174 & 315 & 59 & -179 & -165 & 555 & & 539 \\
\hline StEl & 850 & -70 & 664 & 977 & 1,222 & 1,051 & 816 & 1,076 & 864 & 980 & 553 & \\
\hline
\end{tabular}


In the present study the dent $\mathrm{x}$ dent crosses presented the largest percentage of superior hybrids in Xanxerê, especially crosses involving TuxA, AdB and StEl. In Eldorado do Sul these populations also produced superior hybrids; however, population Cone Sur (flint type) gave highly productive hybrids when combined with dent types. On the other hand, the inclusion of flint germplasm contributed to heterosis in grain yield, number of grains per ear, grain weight, plant height, first ear insertion and percentage of root lodging, indicating that specific flint $\mathrm{x}$ dent combinations may be important in this group of germplasm studied.

\section{Conclusions}

1. The group of 12 populations studied exhibited high genetic variability for agronomic traits; so AdB, $\mathrm{Pb} 62$ and TuxA, St34, and StEl could be highlighted as promising germplasm for maize breeding programs in the Southern Brazil.

2. In these populations, GCA was more important than SCA, indicating high additive variance and suggesting genetic progress through selection.

\section{References}

BRENNER, D.; CARVALHO, F. I. F.; FEDERIZZI, L. C. Estimates of combining ability for grain yield in maize (Zea mays L.) populations. Revista Brasileira de Genética, Ribeirão Preto, v. 14, p. 1001-1009, 1991.

FERREIRA, D. F.; OLIVEIRA, A. C.; SANTOS, M. X.; RAMALHO, J. H. Métodos de avaliação da divergência genética em milho e suas relações com os cruzamentos dialélicos. Pesquisa Agropecuária Brasileira, Brasília, v. 30, n. 9, p. 1189-1194, set. 1995.

GRIFFING, B. Concept of general and specific combining ability in relation to diallel crossing system. Australian
Journal of Biological Sciences, Collingwood, v. 9, p. 463-493, 1956.

HALLAUER, A. R.; MIRANDA FILHO, J. B. Quantitative genetics in maize breeding. 2. ed. Ames: Iowa State University Press, 1988. 468 p.

MIRANDA FILHO, J. B.; VIÉGAS, G. P. Milho híbrido. In: PATERNIANI, E.; VIÉGAS, G. P. (Ed.). Melhoramento e produção de milho. 2. ed. Campinas: Fundação Cargill, 1987. p. 275-340.

MUNGOMA, C.; POLLAK, L. M. Heterotic patterns among ten corn belt and exotic maize populations. Crop Science, v. 28, p. 500-504, 1988.

PÉREZ-VELÁSQUEZ, J. C.; CEBALLOS, H.; PANDEY, S.; DIAZ AMARIS, C. Analysis of diallel crosses among Colombian landraces and improved populations of maize.

Crop Science, Madison, v. 35, p. 572-578, 1995.

PIXLEY, K. V.; BJARNASON, M. S. Combining ability for yield and protein quality among modified-endosperm opaque-2 tropical maize inbreds. Crop Science, Madison, v. 33, p. 1229-1234, 1993.

RITCHIE, S. W.; BENSON, G. O.; LUPKES, S. J.; SALVADOR, R. J. Corn grows. Available on: http:// www.ag.iastate.edu/departments/agronomy/ corngrows.html. Access on: 1998.

STUBER, C. W. Heterosis in plant breeding. Plant Breeding Reviews, New York, v. 12, p. 227-251, 1994.

VASAL, S. K.; SRINIVASAN, G.; CROSSA, J.; BECK, D. L. Heterosis and combining ability of Cimmyt's subtropical and temperate early-maturity maize germplasm. Crop Science, Madison, v. 32, p. 884-890, 1992a.

VASAL, S. K.; SRINIVASAN, G.; GONZALEZ, F.; HAN, G. C.; PANDEY, S.; BECK, D. L.; CROSSA, J. Heterosis and combining ability of Cimmyt's tropical $\mathrm{x}$ subtropical maize germplasm. Crop Science, Madison, v. 32, p. 14831489, $1992 \mathrm{~b}$. 